\title{
Association between Self Reported Questionnaire-determined Physical Activity Level with the Cardiorespiratory Fitness in Adolescent
}

\section{Chandrawati Gultom, Irma Ruslina Defi, Ellyana Sungkar}

Department of Physical Medicine and Rehabilitation, Dr. Hasan Sadikin General Hospital, Faculty of Medicine, University of Padjadjaran, Bandung, Indonesia

\begin{abstract}
Introduction: Cardiorespiratory fitness (CRF) and physical activity (PA) in childhood can reduce the risk of cardiovascular diseases in adults. Further analysis related to the relationship between PA and CRF to prevent an inactive lifestyle is needed

Methods: An analytic cross-sectional design in adolescents aged 13-15 years old, who had no cardiovascular and metabolic diseases, with light or medium physical activity, no deformity in the lower limbs and posture disorders. Cardiorespiratory fitness was assessed by the indirect method Bruce Protocol in the Faculty of Sport and Health Education's library, The University of Pendidikan Indonesia on September-October 2019. Physical activity was measure by the Physical Activity Questionnaire for Adolescent (PAQ-A).

Results: Subjects consisted of 82 adolescents (41 boys, 41 girls), aged 13-15 years old with the Body mass index (BMI) was 18.5-29 $\mathrm{kg} / \mathrm{m}^{2}$. The mean value of predicted $\mathrm{VO}_{2}$ max (Bruce) for boys and girls were $46.66 \pm 8.765$ and $40.06 \pm 6.210 \mathrm{ml} / \mathrm{kg}^{2}$, while the value of predicted PAQ-A score for boys and girls were $2.54 \pm 0.756$ and $2.16 \pm 0.416$. The correlation between PAQ-A and $\mathrm{VO}_{2} \mathrm{max}$ in boys and girls were $\mathrm{r}=0,190, \mathrm{p}=0,234$ and $\mathrm{r}=0.420 ; \mathrm{p}=0.006$.
\end{abstract}

Conclusion: There was a moderate association between PAQ-A with $\mathrm{VO}_{2}$ max in girls.

Keywords: Cardiorespiratory fitness, Physical activity questionnaire, $\mathrm{VO}_{2}$ max. 


\begin{abstract}
ABSTRAK
Pendahuluan: Kebugaran kardiorespirasi dan tingkat aktivitas fisik pada masa kanak-kanak akan menurunkan risiko penyakit kardiovaskular pada masa dewasa. Analisa lebih lanjut terkait hubungan antara aktivitas fisik dan kebugaran kardiorespirasi untuk mencegah gaya hidup tidak aktif sangat diperlukan.
\end{abstract}

Metode: Desain potong lintang analitik dilakukan pada remaja usia 13-15 tahun, yang tidak memiliki penyakit kardiovaskular dan metabolik, dengan tingkat aktivitas fisik ringan-sedang, tidak memiliki deformitas di anggota gerak bawah dan gangguan postur. Kebugaran kardiorespirasi dinilai dengan uji latih Bruce di laboratorium olahraga Fakultas Pendidikan Olahraga dan Kesehatan, Universitas Pendidikan Indonesia pada bulan September-Oktober 2019. Tingkat aktivitas fisik dinilai menggunakan Physical Activity Questionnaire for Adolescent (PAQ-A) dalam versi Indonesia.

Hasil: Sebanyak 82 remaja (41 laki-laki, 41 perempuan), berusia 13-15 tahun dengan Body Mass Index (BMI) $18.5-29 \mathrm{~kg} / \mathrm{m}^{2}$. Nilai rerata prediksi $\mathrm{VO}_{2}$ maks (Bruce) pada remaja laki-laki dan perempuan adalah $46.66 \pm 8.765$ dan $40.06 \pm 6.210 \mathrm{ml} / \mathrm{kg}^{2}$, sedangkan skor PAQ-A remaja laki-laki dan perempuan adalah $2.54 \pm 0.756$ dan 2.16 \pm 0.416 . Korelasi antara PAQ-A and nilai prediksi $\mathrm{VO}_{2}$ maks pada laki-laki dan perempuan adalah $\mathrm{r}=0,190, \mathrm{p}=0,234$ dan $\mathrm{r}=0.420, \mathrm{p}=0.006$.

Kesimpulan: Terdapat hubungan sedang antara PAQ-A dan $\mathrm{VO}_{2}$ maks pada remaja perempuan.

Kata kunci: Kebugaran kardiorespirasi, kuesioner aktivitas fisik, $\mathrm{VO}_{2}$ maks.

Correspondent Detail:

\section{Chandrawati Gultom}

Email: chandrawati.gultom@yahoo.co.id Department of Physical Medicine and Rehabilitation, Dr. Hasan Sadikin General Hospital

Faculty of Medicine University of Padjajaran Bandung, Indonesia

\section{INTRODUCTION}

Recent studies have shown that higher CRF in childhood and adolescence is associated with lower BMI, body fatness, and metabolic syndrome incidence in 2 years later. ${ }^{1-6}$ Physical activity is important for improving cardiorespiratory fitness. Several studies have demonstrated that more active children have better cardiorespiratory fitness. ${ }^{7,8}$ These findings showed a correlation between physical activity and physical fitness, in improving cardiorespiratory fitness. ${ }^{9}$ The development of cardiovascular disease started in childhood and developed along adulthood. Controlling the risk factors earlier is needed and should be done by simple screening tools at school.

Basic Health Research by Indonesian Health Ministry (RISKESDAS) 2018 has showed that inactive young Indonesians age of 10 
years and above, increasing from $26,1 \%$ in 2013 became $33,5 \%$ in 2018 . These results linear with the percentage of obese population over 18 years old, that was also increase from $19,7 \%$ in 2013 , to $21.8 \%$ in 2018 . Those research data also showed prevalence of non communicable diseases, i.e. diabetes mellitus, hypertension, stroke, and heart disease, can be has correlation with poor physical activity and obesity, which also increased from 2013 to $2018 .{ }^{10}$ It is necessary to screening physical activity level of Indonesian adolescents by simple screening tools, to prevent inactivity and promote active lifestyle. Considering the archipelago of Indonesia geographical conditions, then the simple screening tool such as self-administered habitual physical activity questionnaire was needed.

It was difficult to determine the best instruments to assess physical activity, because there was still no gold standard examination. Some instruments that have been used include a variety of physiological indicators, laboratory methods, direct observation, motion sensors, and self-report measures. ${ }^{11}$ Self-report measures are most frequently done for the assessment of physical activity levels in children and adolescents, because they are low in cost and can be easily administered to large populations. In response to the need for a valid and feasible self-report measure for large-scale research with children and adolescents, the Physical Activity Questionnaire for Adolescents (PAQ-A) were developed. ${ }^{12}$ Dapan et al., had validated PAQ-A Questionnaire in Indonesian adolescent and stated that PAQ-A have good and reliable concurrent validity. ${ }^{13}$ Although associations of physical activity that measured by pedometer have been commonly reported, the relationship of self-reported questionnaire physical activity level with CRF in Indonesia children not well established. Therefore, the aim of this study is to investigate whether physical activity levels that measured by self reported questionnaire associated with levels of CRF in adolescent.

\section{METHODS}

This experimental study was reviewed and approved by the research and ethics review committee of Faculty of Medicine, University of Padjadjaran, Bandung, Indonesia. All of the subjects and parents have given their informed consent and filled out the Physical Activity Readiness Questionnaire (PAQ-R) before participating in the study.

The inclusion criteria of the study were adolescents aged 13-15 years old, participant and their parents agree to participate and sign the informed consent. The exclusion criteria of the study were having congenital heart disease, type 2 Diabetes, asthma bronchial, obese $\left(\mathrm{BMI}>30 \mathrm{~kg} / \mathrm{m}^{2}\right)$, and having a deformity in lower extremity and scoliosis.

Eighty-two participants (41 boys, 41 girls) who met the inclusion criteria were recruited at Baptist Junior high School in Bandung. Participants were examined by researcher to confirm the eligibility at Baptist Junior High School auditorium on September-October 2019. Participants who did not follow all of the study procedure or did not attend the exercise testing were dropped out. A selfadministered habitual physical activity 
questionnaire in Indonesian version that has been validated by Dapan et al was used. ${ }^{13}$ The PAQ-A addresses a habitual physical activity in the last 7 days. The PAQ-A consists of three sections, including physical activity in school, during transportation and leisure-time. Each section is further divided into different activity categories. School section: physical education and breaks between lessons with options for different intensity levels, and sitting at lessons. Transportation section: walking and bicycling at least $10 \mathrm{~min}$ at a stretch, and going by a motor vehicle. Leisure-time section: activities at least 10 min long at two different intensity levels along with walking at least $10 \mathrm{~min}$ at a stretch and sitting activities. ${ }^{12}$

Cardiorespiratory fitness assessed by exercise testing to predicting $\mathrm{VO}_{2} \max$ using Bruce protocol at sport laboratory of Sport and Health Education Faculty, University of Pendidikan Indonesia, on September-October 2019. Bruce exercise testing was held not more than 3 days after physical activity measurement. Heart rate of participant recorded by Polar monitor heart rate. Subjects were instructed to walk and run on treadmill (En-Mill) that was programmed for increases in grade and speed every 3 minutes as outlined by Bruce et al. Calibrations for grade and belt speed were checked at frequent intervals. Each subject was urged to continue to the point of severe fatigue and subjects were persuaded to perform maximal or at least very close to maximal exercise. The tested ended while the subject cannot continue the test because of any reason.

This observational analytic study use cross-sectional design. Data was analyzed using Pearson correlation test. Statistically significance was determined with $\mathrm{p}$ value $<0.005$. All statistical analysis performed using SPSS version 21.0 for Windows.

\section{RESULTS}

Total numbers of participants involved in the study were 120 subjects. Random selection of subjects based on the serial number of attendance list. There were 100 participants who met the inclusion criteria. Finally, there were 82 subjects participated in this study, consisting of 41 boys and 41 girls.

Table 1. The Physical Activity and Cardiorespiratory Fitness

\begin{tabular}{ccc}
\hline & Boys & Girls \\
\hline PAQ-A & $2.54 \pm 0.756$ & $2.16 \pm 0.416$ \\
$\mathrm{VO}_{2} \mathrm{max} \mathrm{ml} / \mathrm{kg}^{2}$ & $46.66 \pm 8.765$ & $40.06 \pm 6.210$ \\
\hline
\end{tabular}

Table 2. The correlation between Physical Activity and Cardiorespiratory Fitness

\begin{tabular}{ccc}
\hline PAQ-A and $\mathrm{VO}_{2}$ max & $\mathrm{r}$ & $\mathrm{p}$ \\
\hline Boys & 0,190 & 0,234 \\
Girls & 0.420 & $0.006^{*}$ \\
\hline
\end{tabular}

*Pearson-test

Pearson's correlation test showed the moderate correlation between PAQ-A and $\mathrm{VO}_{2} \max$ in girl $(\mathrm{r}=0.420 ; \mathrm{p}=0.006)$. The PAQ-A and $\mathrm{VO}_{2} \max$ in boys were higher than the girls. 


\section{DISCUSSION}

This study analyzed the relationship between physical activity level using PAQ-A questionnaire and cardiorespiratory fitness $\left(\mathrm{VO}_{2} \max \right)$ in Adolescent. The results study showed moderate correlation between PAQ-A questionnaire and $\mathrm{VO}_{2} \max$ in girls. This evidence demonstrated that a girl who was physically active might have higher cardiorespiratory fitness level than inactive children. The data from this study was similar with result study by Latt et al. , that observed the American youth. ${ }^{12}$ Another research by Aires et al in Portugal showed relationship between physical activity with cardiorespiratory fitness. Aires used physical activity index to measure physical activity. ${ }^{7}$ Adequate physical activity will affect the distribution of minute ventilation, distribution of muscle fibers type and body composition, which was in turn affects cardiorespiratory fitness. ${ }^{12}$

The data from this study has showed moderate correlation between the score of PAQ-A and the $\mathrm{VO}_{2} \max$, while there was no correlation as in boys. Voss et al showed only weak correlation between PAQ-A score in adolescent boys ( $\mathrm{r}=0,273, \mathrm{P}<0,001) .{ }^{14}$ Such typical weakto-moderate associations between CRF and PA may in part be explained by genetics, which accounts for up to $30 \%$ of the variance in CRF and responsiveness to training. ${ }^{15}$ Peter et al have found the fact that PAQ-A have inability to capture duration and intensity of PA. ${ }^{16}$ Duration and intensity of physical activity are related to $\mathrm{VO}_{2}$ max in a dose-response manner. ${ }^{6}$ Another limitations of self-administered habitual physical activity questionnaire may be limited by the dependency on written language (i.e., questions) and external factors (i.e., social desirability, complexity of the questionnaire, age, and seasonal variation). ${ }^{16}$ Despite of PAQ-A limitations author observed that there is associations of expected strengths and direction of PAQ-A as a tool to estimate general levels of PA.

This study has limitation, i.e. the lack number of subjects, the subjects recruited only from one location, the PAQ-A was subjective examination that can be deviation, particularly when the subjects were not focus. Therefore, the result from this study regarding relationship between physical activity and cardiorespiratory fitness levels in adolescent girls should be interpreted carefully. The results of this study can be generalized to the similar populations. Another limitation was the cardiorespiratory fitness assessed by indirect measurement of VO2max. However, previous studies have demonstrated a high correlation between $\mathrm{VO}_{2}$ max indirect and direct in Bruce exercise testing. ${ }^{17,18}$

\section{CONCLUSION}

The self-reported questionnaire (PAQ-A) to determined physical activity level has a moderate association with cardiorespiratory fitness in girls. The self-reported questionnaire to determined physical activity can be used to assessed the physical activity level, and to predict the cardiorespiratory fitness as a health predictor in girls. 


\section{REFERENCES}

1. Telford RD, Cunningham RB, Waring P, Telford RM, Potter JM, Hickman PE, et al. Sensitivity of Blood Lipids to Changes in Adiposity, Exercise, and Diet in Children. Medicine \& Science in Sports \& Exercise. 2015; 47(5): 974-82.

2. Henderson $\mathrm{M}$, Benedetti A, Barnett TA, Mathieu M-E, Deladoëy J, GrayDonald K. Influence of Adiposity, Physical Activity, Fitness, and Screen Time on Insulin Dynamics Over 2 Years in Children. JAMA Pediatrics. 2016; 170(3): 227.

3. Jekal Y, Kim Y, Yun JE, Kim ES, Naruse $\mathrm{M}$, Park JH, et al. The Association of Adolescent Fatness and Fitness With Risk Factors for Adult Metabolic Syndrome: A 22-Year Follow-up Study. Journal of Physical Activity and Health. 2014;11(4): 823-30.4.

4. Sun C, Magnussen CG, Ponsonby A-L, Ponsoby A, Schmidt MD, Carlin JB, et al. The contribution of childhood cardiorespiratory fitness and adiposity to inflammation in young adults: Fitness, Fatness, and Inflammation. Obesity. 2014; 22: 2598-605.

5. Schmidt MD, Magnussen CG, Rees E, Dwyer T, Venn AJ. Childhood fitness reduces the long-term cardiometabolic risks associated with childhood obesity. International Journal of Obesity. 2016; 40(7): 1134-40.

6. Lopes VíP, Maia JAR, Rodrigues LP, Malina R. Motor coordination, physical activity and fitness as predictors of longitudinal change in adiposity during childhood. European Journal of Sport Science. 2012; 12(4): 384-91.

7. Aires L, Pratt M, Lobelo F, Santos RM, Santos MP, Mota J. Associations of cardiorespiratory fitness in children and adolescents with physical activity, active commuting to school, and screen time. Journal of Physical Activity and Health. 2011; 8 Supp1 2: 198-205.

8. Boddy LM, Fairclough SJ, Atkinson G, Stratton G. Changes in cardiorespiratory fitness in 9- to 10.9-year-old children. Med Sci Sport Exerc. 2012; 44(3): 481-6.

9. Hsieh P-L, Chen M-L, Huang C-M, Chen W-C, LiC-H, Chang L-C. Physical activity, body mass index, and cardiorespiratory fitness among school children in Taiwan: a cross-sectional study. International Journal of Environmental Research and Public Health. 2014; 11(7): 7275-85.

10. Kemenkes RI. Hasil Riskesdas 2018. Jakarta: Balitbang; 2018.

11. Sylvia LG, Bernstein EE, Hubbard JL, Keating L, Anderson EJ. Practical Guide to Measuring Physical Activity. Journal of the Academy of Nutrition and Dietetics. 2014; 114(2): 199-208.

12. Dapan, Andriyani FD, Indra EN, Indiawati MP, Subeni T, Ramadona ET. Uji validitas dan reliabilitas instrumen physical acticity questionnaire for older children (PAQ-C) dan physical activity for adolescent (PAQ-A). Yogyakarta; Laporan Penelitian dan Pengembangan Bidang Ilmu Keolahragaan; 2017. 
13. Lätt E, Mäestu J, Rääsk $T$, Jürimäe T, Jürimäe J. Cardiovascular fitness, physical activity, and metabolic syndrome risk factors among adolescent estonian boys: A longitudinal study: fitness, physical activity, and metabolic syndrome. American Journal of Human Biology. 2016; 28(6):782-8.

14. Barnes KR, Kilding AE. Running economy: measurement, norms, and determining factors. Sports Medicine. 2015;1(1).

15. Voss C, Ogunleye AA, Sandercock GR. Physical Activity Questionnaire for children and adolescents: English norms and cut-off points: Norms and cut-off points for PAQ-C/-A. Pediatrics
International. $2013 ; 55(4): 498-507$.

16. Malina RM. Physical activity as a factor in growth and maturation. Human Growth and Development. 2012: 375-396.

17. Lassenius O, Åkerlind I, Wiklund-Gustin L, Arman M, Söderlund A. Self-reported health and physical activity among community mental healthcare users: selfreported health and physical activity. Journal of Psychiatric and Mental Health Nursing. 2013; 20(1): 82-90.

18. Peric R, Nikolovski Z. Validation of four indirect vo2max laboratory prediction tests in the case of soccer players. Journal of Physical Education and Sport. 2017; 17(2): 608-13. 